\title{
A Detail Study of the Genus Vallatisporites as a Lower Carboniferous Stratigraphic and Paleogeographic Indicator
}

\author{
Amer D. Nader Maha A. Al-Hasson Yasser H. Kaddo \\ Department of Geology \\ College of Science \\ Mosul University
}

(Received 3/5/2007 , Accepted 19/6/2007)

\begin{abstract}
The genus Vallatisporites Hacquebard emend. Sullivan 1964b is studied in detail due to it's biostratigraphical and paleogeographical significance in the Carboniferous strata on a global scale. This cosmopolitan genus is widely used in chronostratigraphy and many of its species are used as a zonal fossils in different zonal schemes.

The common occurrence of the majority of the species belonging to this genus in the Carboniferous strata recorded in two boreholes in Iraq (Akkas-1 and Kh5/1), demanded detail study. Samples from borehole Akkas-1 which represented Lower Carboniferous (Late Visean-Early Namurian) age were critical to this study because they contained most of the Vallatisporites index species, especially the distinctive indemic, index species V.agadesi for the Visean / Namurian age in the North Africa and Middle East (including Iraq).

The present study provided an additional existence of the most zonal Vallatisporites spp. in the world, the ranges of some key forms of Vallatisporites in Iraq, neighboring areas and North Africa are different from those observed elsewhere which reflect that Iraq, adjacent areas and North Africa belong to the same phytogeographical province during the carboniferous period. In addition to that we take in to consideration the recent differentiation between $V$. pusilletes and $V$. hystricosus by the Vallatisporites Group and we consider all the Vallatisporites pusilletis recorded in the two boreholes studied as $V$. hystricosus. The botanical affinities of the genus Vallatisporites is Pteridophytes (Lycopsids).

درلسة فهصيلية للنوع Vallatisporites كأحد أجناس الكاريوفي لأسطل ذو الدلالة اللبلفية المميزة
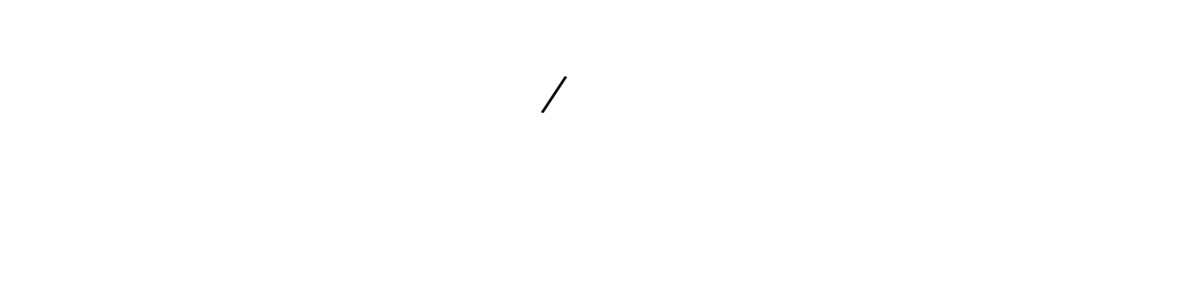

دس الجنس Vallatisporites المستحدث من قبل Hacquebard (1957) والمعل وصفه من قبل درلسة تفصيلية لاهميته الطباقية وانتشاره الجغرافي في صخور الكاربوفي الإسفل في
\end{abstract}


العالم،لقد لستعملت الاذواع الدالة لهذا الجن العالمي الولسع الانتشار في العديد من المخططلت الظاقية

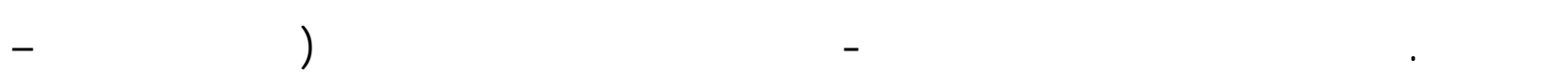

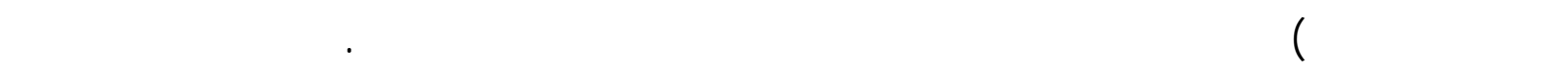

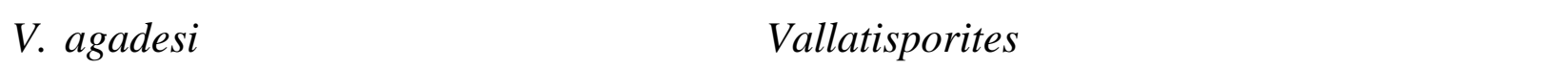

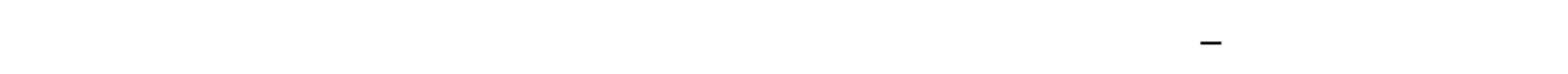
الاوسط (بضمنها العراق).

اضفت الدرلسة الحالية لمتدادا للمديت المثبته عالميا لانواع Vallatisporites كون العراق يمل

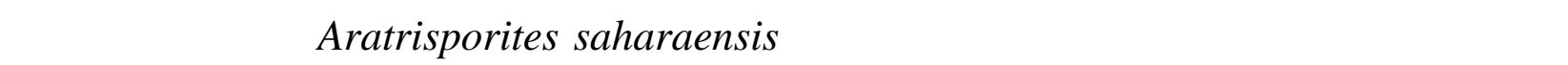
للسعودية، ايران وشمل افريقيا والتي تختلف عن المطقة النباتية لجن اوربا وامريكا للثمالية وتركيا.

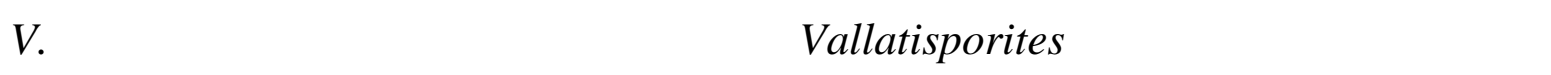

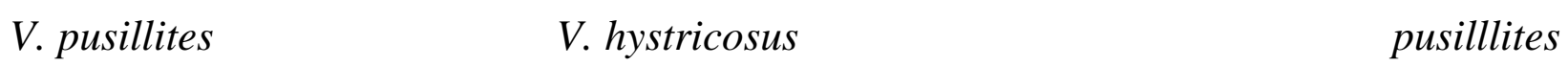

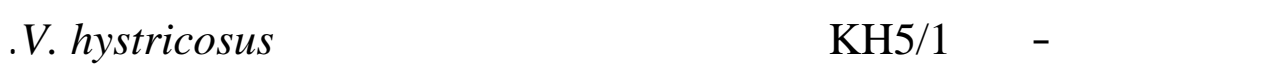

\section{INTRODUCTION}

Approximatly 30 species have been assigned to this genus over the 45 years ago and some have been designed as index fossils in the Palynozonal schemes around the world. The generic description was first proposed by Hacquebard (1957) and later emendations allow to accommodate many cingulizonate and zonate form. This wide range morphologies led us to compare this genus with similar genera to clarify the relationships between them. The relation of the genus Vallatisporites to Carboniferous provincialism and the provincialism idea during the Carboniferous period has been adopted by Sullivan (1965) and late extended and refined by Turnau (1978) and Van der Zwan (1981).

Clayton (1985) has reconstructed five microfloral provinces during the late Devonian(Strunian) to the Carboniferous(Tournaisian,Visean, and Namurian)age, these are: The north temporate Province(known from the soviet union), the equatorial Province(known from boreal areas), the southern subequatorial Vallatisporites Province(known from Europe, south eastern Canada and Turkey), the latitudinal Province and the southern temporate to sub-polar Aratrisporites saharaensis microfloral Province(known from North Africa, Brazil and Middle East such as Iran by Coquel et al. (1977), Syria by Ravn et al. (1994), Saudi Arabia by Clayton et al. (2000) and Owens et al. (2000). 


\section{Aim of this study}

The aim of this study is to prove and support the Carboniferous provincialism and that Iraq should assigned to the Aratrisporites province which include Syria, Saudi Arabia, Iran and North Africa rather than its representing Vallatisporites province of Clayton (1985) which include Turkey, western Europe and North America by using the stratigraphically Carboniferous indicator and the cosmopolitan genus Vallatisporites. One of the key consequences of the Carboniferous provincialism is the strong disparity in the stratigraphic distribution of the cosmopolitan taxa that recorded in these different provinces such as the differences in the stratigraphic distributions of the species that assigned to Vallatisporites, the second key is the confirmation of the existence of the endemic species of this genus, in the different provinces for this reason samples from borehole Akkas-1 which equated late Visean to early Namurian age were chosen to this study because they included the common occurrences of the most index species of the genus Vallatisporites, especially the occurrence of the endemic, index species V. agadesi which restricted to the North Africa and Middle East (this study).

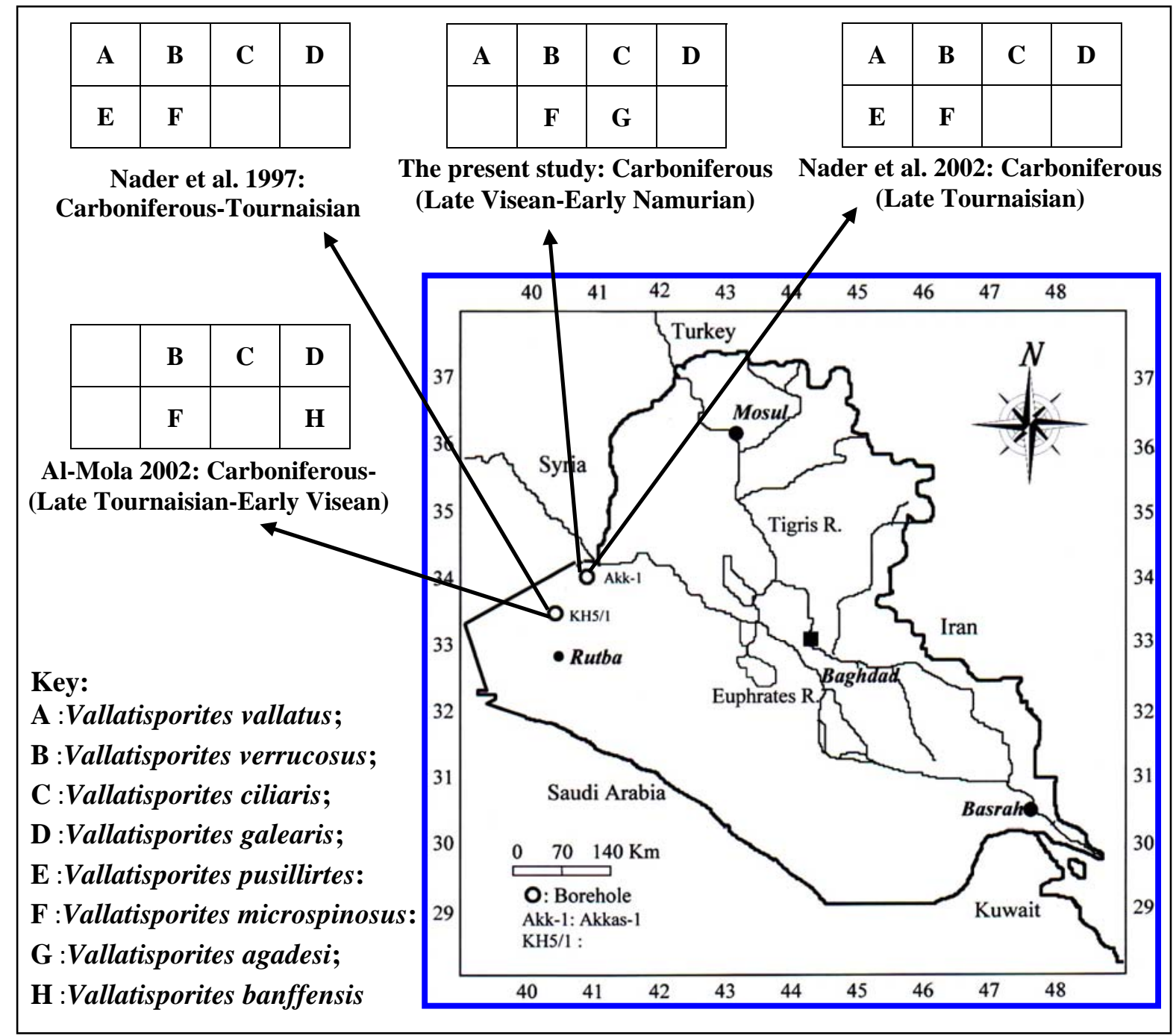

Fig.1: Shows: -Location of boreholes Akkas-1 and KH5/1.

-Distribution and correlation of the Vallatisporites species in Carboniferous strata in Iraq. 


\section{SYSTEMATIC PALYNOLOGY \\ ANTETURMA Proximegerminates R. Potonie 1970 \\ TURMA Triletes Reinsch emend. Dettman 1963 \\ SUPRASUBTURMA Laminatitriletes Smith and Butterworth 1967 \\ SUBTURMA Zonolaminatitriletes Smith and Butterworth 1967 \\ INFRATURMA Cingulicavati Smith and Butterworth 1967 \\ Genus Vallatisporites Hacquebard emend. Sullivan 1964b \\ Type species: Vallatisporites vallatus Hacquebard 1957}

Discussion: Hacquebard 1957 formulated the following original description: spores radial triletes; proximal view convexly subtriangular; trilete not always distinct, rays extending in to flange; central body thin with well defined margin, subcircular to broadly roundly triangular in outline, perispore extends beyond body margin and thickens into narrow "ridge" characterized by a single row of pits (visible in high focus), from which it tapers to equator in the form of a flange; area between body margin and perisporal "ridge" may vary from a few microns, in which case it appears like a groove, to as much as 8 microns, becoming rampart-like in appearance, central area covered with grana, small cones or warts; flange may contain rodlets and cones radiating from perisporal "ridge" and gradually becomes thinner and more translucent towards periphery; diameter 55-84 microns.

\section{Description of the type species:}

The original diagnosis by Hacquebard (1957) has been acceptably modified by Sullivan (1964b) and Staplin and Jansonius (1964). Sullivan (1964b) noticed a groove that had named a Cuniculus which located between the equater of the spor cavity and the inner surface of the equatorially exoexine. The author recognized an ornamentations of grana, cones verrucae or spines on the distal exoexine as well as on the proximal regions of the equatorial border.

Staplin and Jansonius (1964) confirmed the presence of a groove or Cuesta, although they assigned that the vacueles in some species opened to the distal surface forming a system of cusp-to awl-shaped depressions.

Neves and Owens (1966) transferred the genus Vallatisporites to the Subturma Membranatitriletes

Remarks: The genus Vallatisporites is distinguished from other morphologically similar genera of infraturma Cingulicavati Smith and Butterworth (1967) by the development of internal vaculations (vacuoles are rounded to elongated spaces within an equatorial feature) which located at the internally equatorial border and by the presence of a distinct groove separating the central body from the equatorial portion, this lighter groove named Cuniculus (fig.2).

Currentely a superficial reivw of the genus Vallatisporites suggests that the genus may be accommodating at least two major groups of species e.g.the typical $V$. vallatus N.verrucosus complex which characterized by a narrow, thickened equatorial extension with limited vacuolation of the structure and by a prominent distal ornamentation while, another group containing R. V.genuinus/V.arcuatus which characterized by a highly vacuolate, thin and wide equatorial extention bearing minimal ornamentation. 
Acritical comparisons are achieved between this genus and other similar genera:

1-Genus: Densosporites Berry emend. Butterworth, Jansonius, Smith and Staplin 1964

Remarks: The most characteristic feature of this genus is the presence of a psilate, granulose, apiculose, spinose and verrucose cingulum which lacking vacuolations.

2-Genus: Cristatisporites Potonie and Kremp emend. Butterworth Jansonius, Smith of Staplin 1964.

Remarks: The most characterstic freature of the genus is the mamoid (warts) or setose distal sculpter and the presence of minute foveolae at the inner surface of the exoexine.

3-Genus: Cirratriradites Wilson and Koe 1940.

Remarks: This genus is characterized by its radially striate and marginally serrate flange (zona) which may distally foveae.

4-Genus: Radiizonites Staplin andJansonius 1964.

The main characteristic feature of this genus its zona which differentiated to the inner part and the outer part which is characterized distally by radial striae or ribs.

5-Genus: Kraeuselisporites (Leschik) Jansonius 1962.

The main characteristic feature of this acavate form is the zonate nature of equatorial extention of the exine which lacks internal vacuolation, although some auther assigned the genus to cavate forms.

Infraturma Continuati Neves and Owens 1966

\section{1-Genus: Spinozonotriletes ( Hacquebard ) Neves and Owens 1966}

Remarks: It is camerate miospore in which the exoexine attached to the intexine on both proximal and distal surfaces . the exoexine extended to form a flange which is resticted only to the equatorial plane. The distal and the equatorial area of the proximal surface of the exoexine ornamented with stout cones or spi.nes.

\section{Infraturma: Decorati Neves and Owens 1966}

\section{2-Genus :Spelaeotriletes ( Leschik ) Jansonius 1962}

Remarks: This Camerate miospore genus is characterized by the two exine wall layers in which attached only on the proximal surface and by the thinner inner membrance or intexine which is darkened in polar view. The ornamentation is mainly small cones, grana, verrucae, which may show variable lateral fusion forming short irregular ridges. 
Distinctive species of the genus Vallatisporites Hacquebard emend. Sullivan 1964b from the carboniferous of Iraq

\section{1-Vallatisporites vallatus Hacquebard 1957}

\section{pl.1, figs. 10-12, 12}

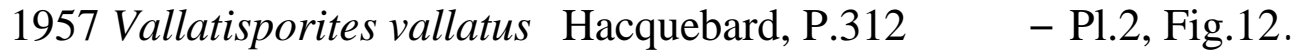

Description: (From Hacquebard 1957): Spores radial trilete; convexly subtriangular in proximal view; trilete usually distinct, lips slightly raised, extending to equator or nearly so; central body thin, margin well defined, often folded; in central area, perispore has minute grana and small cones, 1-2 microns in diameter, 2-3 microns apart; perisporal extension with rampart-like inner part, up to 8 microns wide, and flange-like outer part, 6-10 microns wide; where the two parts meet, perispore is thickened and contains a single row of pits, visible in high focus; flange like portion has minute cones small grana, membranous border, and finely toothed outer margin.

Size 50 (59) $70 \mu \mathrm{m}$, body 35-41 microns.

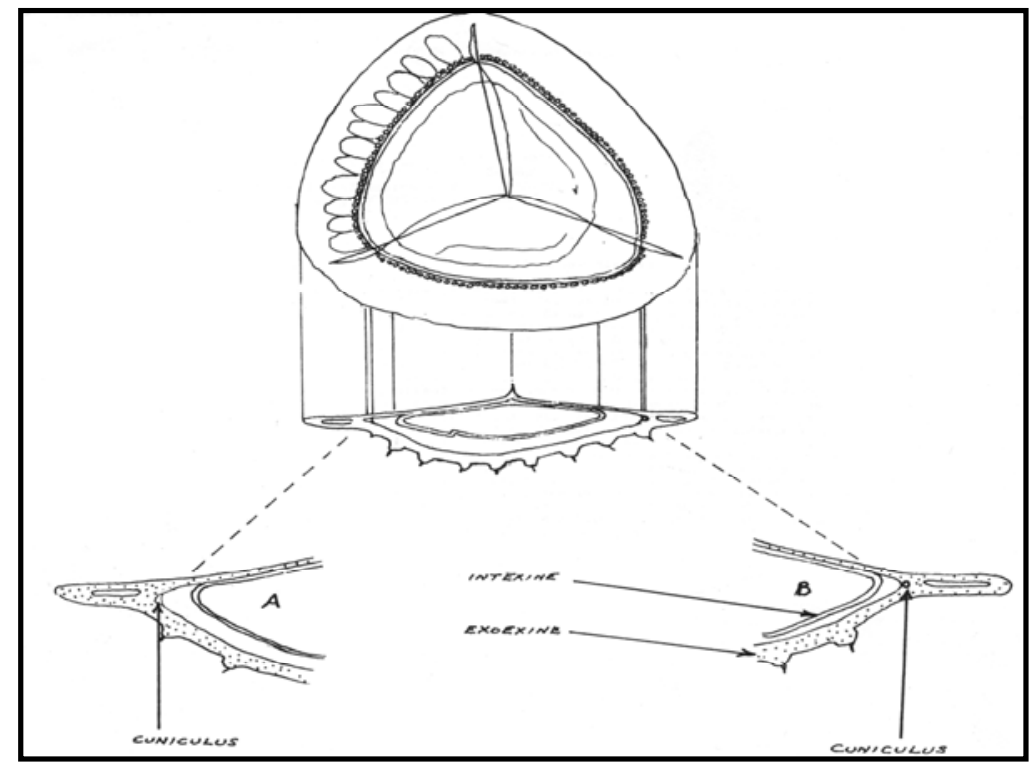

Fig.2: Vallatisporites diagrammatic reconstruction of proximal view showing internal vacuoles and the cuniculus.

A: Note the position of the cuniculus appears to be within the cavity created by the separation of the intexine from the exoexine within the equatorial plane. This concept could be acceptable in the initial phases of the process of separation which presumably took place in the equatorial plane. The problem however is the cuniculus would disappear when the process of separation progressed beyond the initial phase and the separation began to spread towards the distal pole.

B: In this example, the cuniculus appears to be a feature within the exoexine. As a discrete structure it could continue to exist regardless of the extent of the separation of the exine layer. If the cuniculus is a consistent structure regardless of the extent of exine layer separation, it might support the original view of Hacquebard that it represent a discrete row of pits (depressions) on the proximal surface of the spore. 
Comparison: Sullivan (1964b) stated that the equatorial region of the proximal surface as well as the distal exoexine ornamented with grana, cones, verrucose and spinose

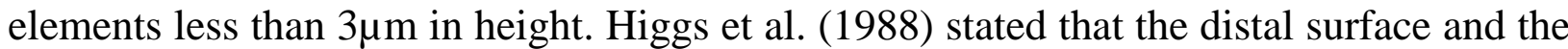
cingulum of $V$. vallatus bears a dense ornament of coni, grana and fine spines

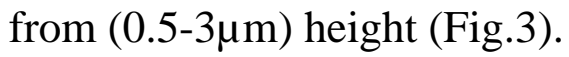

Remarks: Clayton et al. (1977b) defined the base of the upper Vallatisporites vallatusRetusotriletes incohatus (VI) Subzone of the NV Zone from western Europe, by the first appearance of the two bizonal index species at the base of this unit.

Results: From fig. (4) we found that there is disparities between the upper range of V.vallatus in Iraq(this study), Syria, Saudi Arabia and North Africa which extended to Visean and early Namurian age with those recorded from Europe and North America which limited its upper range to the late Tournaisian age,.therefore the present study concluded that the upper range of V.vallatus should be corrected to be late Visean- early Namurian age and that Middle East(including Iraq) and North Africa reflect the same paleogeographic province(Aratrisporites saharaensis) during the Carboniferous period.

\section{2-Vallatisporites verrucosus Hacquebard 1957}

pl.1, figs. 13, 14

I90V Vallatisporites verrucosus Hacquebard, P.312, Pl.2, Fig.13.

Comparisons: $V$. verrucosus differs from $V$. vallatus only in the style of ornamentation which are verrucae instead of cones, grana, and spines. (Fig.3).

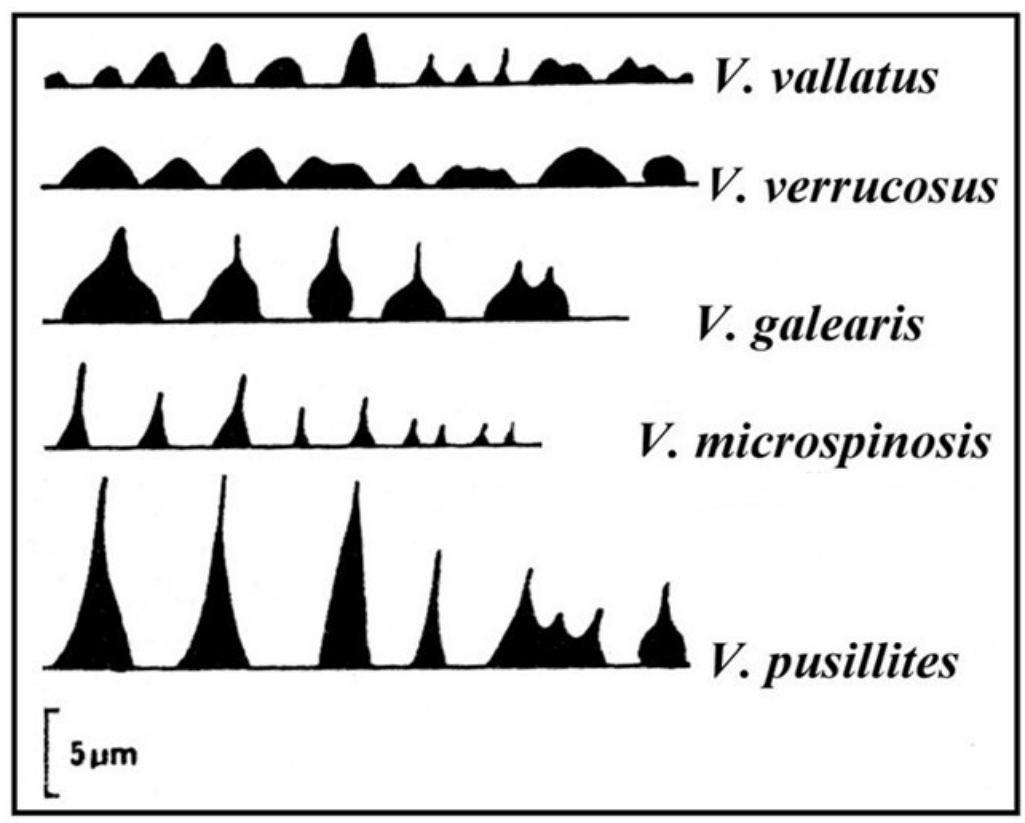

Fig.3: Comparison of ornament in five species of Vallatisporites (Higgs et al., 1988) 
Remarks: Clayton et al. (1977b) defined the base of the NV Zone by the first appearance of Vallatisporites verrucosus together with Verrucosisporites nitidus in western Europe.

Results: From fig. (4) we found there is disparities between the upper range of V.verrucosus in Iraq(this study), Syria, Saudi Arabia and North Africa which extended to Visean and early Namurian age with those recorded from Europe and North America which limited its upper range to the late Tournaisian age.Therefor the present study concluded that the upper range of V.verrucosus should be corrected to be late Viseanearly Namurian age and that Middle East(including Iraq) and North Africa reflect the same geographic province(Aratrisporites saharaensis) during the Carboniferous period.

\section{3-Vallatisporites ciliaris (Luber) Sullivan 1964b}

\section{pl.1, figs. 3-6}

१ १ऍ^ Zonotriletes ciliaris Luber in Luber and Waltz Pl.6 , Fig.82.

197દb Vallatisporites ciliaris (Luber) Sullivan PP.370-372, Pl.59, Figs.14-15.

Comparison: Sullivan (1964b) remarked that V. ciliaris is characterized by cones with rounded or pointed crests up to $3 \mu \mathrm{m}$ with galeae, He differentiated $V$. ciliaris from V.communis Sullivan (1964b) by lacking a well- marked ornamentation on the distal surface of the border and by big size of the elements over the remainder of the region. $V$. ciliaris differs from others by possessing connate/galeate spines.

Results: From fig. (4) we concluded that there is compatible in the upper range of this species around the world,while its lower range is incompatible from early Visean in Europe and Britain in to late Tournaisian in Middle East (Iraq) and North Africa. The present study concluded that lower range of $V$. ciliaris should be corrected and downed to be late Tournaisian age.

\section{4-Vallatisporites galearis Sullivan 1964b} pl.1, fig. 15

$197 \varepsilon b$ Vallatisporites galearis Sullivan ,Pl.59, Figs.17 -19 .

Comparison: This species differs from others by the style and the size of its ornaments which are galeae (fig.3). V.microgalearis is smaller in size and the distal ornaments are found on the central body as well as the cingulum.

Result: There is compatible in the lower and upper ranges of $V$. galearis in Iraq and adjacent areas with those observed elsewhere in the world.

\section{7-Vallatisporites pusillites (Kedo) Dolby and Neves 1970}

190V Hymenozonotriletes pusillites Kedo in part p.22, pl.1, fig.1.

$197 \%$ Hymenozonotriletes pusillites (Kedo) Kedo, p.66, pl.6,figs. 138-140,142; non fig. 141

1970 Vallatisporites pusillites (Kedo) Dolby \&Neves p.639, pl.2,fig.3-4; non figs.1-2 
1985 Vallatisporites pusillites (Kedo) Dolby \& Neves1970 emend. Byvsheva, p.135136,pl.27,figs.1-3.

Description (from Higgs et al., 1988, p.80): Trilete cinguli-camerate miospores; amb usually convexly triangular. Suturae distinct to obscure, bordered by ray folds up to $5 \mu \mathrm{m}$ in height, which appear to extend the suturae to the equatorial margin. Intexine distinct, laevigate ot infragranulate, outline conformable with the amb and exending approximately $1 / 2$ to $3 / 4$ the total spore diameter. Eoexine extended equatorially forming a thin cingulum. The cingulum bears a row of radially aligned vacuoles, $3-7 \mu \mathrm{m}$ in radial length along the inner margin. The outer part of the cingulum is $4-10 \mu \mathrm{m}$ in width. Separation between the intexine and exoexine sometimes occurs, which results a in

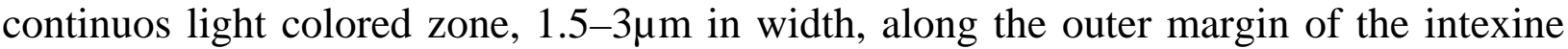
(cuniculus of sullivan 1964b, p.370). The distal and equatorial exoexine are ornamented with spinae and galeae 4-12 $\mu \mathrm{m}$ in height and up to $6 \mu \mathrm{m}$ in basal diameter. Elements discrete, approximately $6 \mu \mathrm{m}$ apart, or fused at their bases, usually in groups of two or three.

Size range: $50-80 \mu \mathrm{m}$ (basal on over 100 specimens).

Comparisons: The suspected occurrences of V.pusilletes (Kedo) Dolby and Neves 1970 in the Carboniferous starta of Iraq (fig.1) demanded this detailed study of this species. Byvsheva (1985) assigned that the Russian concept of the species $V$. pusillites embraces only forms with small, spines(1- $3 \mu \mathrm{m}$ in height ). This Russian circumscription of $V$. pusillites contrasts with the much broader concept described by Dolby and Neves (1970). These authors and many subsequent western palynologists have included coarsely ornamented specimens, (spines greater than 3 microns) within to $V$. pusillites (fig.3). Owens (personal communication) differentiated V.hystricosus Byvsheva (1985) from $V$.pusillites by its larger size wide cingulated structure and ornaments of coarser spinae and galeae (3-16 $\mu \mathrm{m}$ in height), so that it is now clear that longer ornamented forms of $V$. pusillites should be regarded as accommodate forms of V.hystricosus.

Remarks: Clayton et al. (1977b) defined The base of the upper (VI) Subzone of (NV) Zone which equivalent to the Devonian/Carboniferous boundary (early Tournaisian,Tn1b age) by the disappearance of both $V$. pusillites and Spelaeotriletes lepidophytus in western Europe.Other authors restricted the upper range of V.pusillites to strata not younger than Devonian early Tournaisian (Tn1b) age around the world (fig.4), which disparities with their occurrences in the lower Carboniferous (Tournaisian) strata from Iraq accoriding to Nader et al. (1997) and Nader et al. (2002) (fig.1).

Result: This suspected occurrences of $V$. pusillites in the Carboniferous (Tournaisian) strata in Akkas-1\&Kh5/1 boreholes from Iraq, without any evidence of their representations in horizons younger than Devonian (early Tournaisian) age accoriding to other previous studies from Iraq, adjacent areas and the world (fig.4), resulted that these representations of $V$. pusillites in these two boreholes from Iraq should need re-correction their assignments to the species $V$. hystricosus which have coarser ornaments. $V$. pusillites regards accomedating to the $V$. hystricosus accoriding to Byvsheva (1985). 
10-Vallatisporites microspionosus Higgs et al., 1988 pl.1, figs. 7-9

I 9 V O Vallatisporites sp. A Higgs, P.401, pl.7, Figs .7, 11.

1988 Vallatisporites microspinosus Higgs et al., p.80, pl.16,figs.8,12,16; text-fig.33.

Comparison: Higgs et al. (1988) differentiated V. microspinosus from $V$. pusillites in having smaller ornaments and size. The author also differentiated the former species from $V$. vallatus which has larger size (60-70 um ), has an ornament of mainly coni and grana, and possesses a laevigate intexine(Fig.3).

Result: This species was recorded from lower Carboniferous (Tournaisian) strata to the late Visean-early Namurian age from Iraq,without any occurrences from adjacent areas. This occurrence was dispartity with Higgs et al. (1988) who has limited its lower and upper ranges to late Tournaisian age in Ireland (fig.4).

\section{1-Vallatisporites agadesi Loboziak and Alpern 1978} pl.1, figs. 1, 2

1969 Vallatisporites no.3324 Lanzoi Magloire, pl.3, figs.7, 8.

I 9 VV Vallatisporites sp. A Coquel et al., pl.3, fig.1.

1978 Vallatisporites agadesi Loboziak \& Alpern, p.133-134, pl.24, fig.4.

Diagnosis (informal translation of Loboziak and Alpern 1978): Zonate trilete spores. Equatorial contour subtriangular to oval. triangular. Branches of trilete mark distinct, with elevated lips, commonly sinuous and extending to the equator of the spore. Exine consists of two layers. Intexine thin often with concentric folds. Exoexine rugulose and completely surrounding the inner body and extended in the equatorial plane to form a flange with radially elongated vacuoles. Maximum thickness of the exoexine in the inner zone of the flange. Distal surface vermiculate to very coarsely reticulate. Ornamentation elements irregulars relatively strong convolutions and regulae.

Description: These zonate spores have subtriangular equatorial outline with convex to almost straight sides and rounded apices. The branches of the trilete mark are visible and reach almost to the equator. These are almost sinuous and bordered by narrow elevated or sometimes folded lips. The two layers of the exine show the outline of the inner body, a light zone of "Separation" is visible in some individuals. The flange is thickened in its internal part where it forms a circular ring, with the great thickness. The outer part of the flange is thinner and bears several types of small cones visible in particular on the equatorial outline, internal depressions or vacuoles with ovoid, circular or fusiform shape. The radial alignment of these vacuoles, their numerical abundance in certain cases and their rather irregular distribution, with the exception of those adjacent to the thickened darkened inner ring, give the flange a fibrous appearance. The ornamentation 
of the distal surface consists of a vermicular network of large muri of variable height composed of verrucose and connate elements fused at their bases and of shallow wormlike furrows which are sometimes joined to delimit a variable sized meshwork. This ornamentation is only located on the central part of the spore and the thickened inner ring like part of the flange, only occasionally extending on to the thinner outer part of the flange in the form of elongate spinose elements.

Size: Equatorial diameter 60 (69) 80 um

Width of flange 10 (13) 18 um

Remark: The detailed study of the index species $V$. adagesi was necessary in this study because it regards an endemic Gondwanan species for Visean/Namurian strata which restricted to the North Africa and Middle East icluding Iraq (this study) (fig.1).

V.adagesi ranged from Visean to early Namurian age without any occurrences in Tournaisian age from North Africa.,Saudi Arabia and from Iraq (this study). Ravn et al. (1994) has found suspected occurrence of V. agadesi in strata equated Tournaisian ? to early late Visean age from northeast Syria (fig.4).

Result: This study concluded that there is compatible in the lower and upper ranges of endemic species $V$. adagesi in North Africa and Midddle East including Iraq (figs.1,4) which equated Visean to early Namurian age, and provided a strong evidence that Iraq during the Carboniferous period should related to Aratrisporites saharaensis province which include (Syria, Saudi Arabia, Iran \& North Africa), rather than Vallatisporites province which included Turkey, Europe and North America. The second result is the suspected occurrences of $V$. agadesi in the Tournaisian strata from Syria may due to contamination.

\section{2-Vallatisporites banffensis Staplin and Jansonius 1964}

Description (Owens personal communication): Spores trilete, two layered; convexly triangular in polar view; intexine seldom preserved, laesurae not visible, probably involved in the raised sutural ridges of the outer layer; exoexine completely encloses intexine, central proximal surface chagrinate with raised sutural ridges that override the slightly raised cuesta and stop near the outer margin of the internal vacuolation, the cuesta roughly defines the margin of the central cavity and also forms the inner part of the zona; summit of the cuesta coarsely chagrinate, outer margin of the cuesta irregular; outer portion of the zona psilate with widely scattered minute granules, 2-3 times wider than cuesta, outer margin of cuesta smooth with scattered minute apiculae or roughened to serrate; distal surface of exoexine complex, variable, central distal and inner half of the zona irregularly verrucose to apiculate, the central verrucae sometimes partly coalesced, sometimes obscure, replaced by scattered apiculae on some specimens; mid-portion with scattered apiculae and characterized by cusp to awl-shaped depressions that in part are continued as internal vaculose and that are more or less radial in arrangement; outermost portion of the zona psilate with scattered apiculae that in part have minute setose tips, in cross section the spore is flaty convex and the zona strongly tapered.

Size: $74(60) 48$ 
Comparison: Owens (Personal communication) stated that the grains of $V$. banffensis are commonly corroded, emphasizing the cusp shaped depressions and ridges on the mid-zona, and the internal vacuoles. He assigned that $V$. vallatus has completely internal vacuoles, very indistinct proximal separation of central proximal surface and zona, and finer distal sculpture than $V$. banffensis. It differs from V.splendens Staplin \& Jansonius 1964 by its larger stutural ridges and by the presence of cuesta which is in $V$. splendens.

Remarks: A detailed study of $V$. banffensis was necessary, because $V$. banffensis was recorded in the late Tournaisian to early Visean strara from Iraq (fig.1) and Syria. Ravn et al. (1994) who stated that this species was confined by previous workers to the early Tournaisian and older strata elsewhere in the world.

Result: The present study concluded that the upper range of V.banffensis should be raised from early Tournaisian (Tn1b) to the late Tournaisian-early Visean.The disparities in the ranges between Iraq and adjacent area with those observed elsewhere in the world reflects the differences in the provinces.

\section{Occurrence}

The table below summarize the occurrence of the species of Vallatisporites encountered in different parts of the world.

\begin{tabular}{|c|c|c|c|c|c|c|c|c|c|c|c|c|c|c|c|c|c|c|c|c|c|}
\hline & 1 & $\boldsymbol{r}$ & $\mathbf{r}$ & $\varepsilon$ & 0 & 7 & $\mathbf{v}$ & $\boldsymbol{\Lambda}$ & 9 & $\begin{array}{l}1 \\
.\end{array}$ & $\begin{array}{l}1 \\
1\end{array}$ & $\begin{array}{l}1 \\
r\end{array}$ & $\begin{array}{l}1 \\
r\end{array}$ & $\begin{array}{l}1 \\
\varepsilon\end{array}$ & $\begin{array}{l}1 \\
0\end{array}$ & $\begin{array}{l}1 \\
7\end{array}$ & $\begin{array}{l}\mathbf{l} \\
\mathbf{v}\end{array}$ & $\begin{array}{l}1 \\
1\end{array}$ & $\begin{array}{l}1 \\
9\end{array}$ & $r$ & $\begin{array}{l}r \\
\text { r }\end{array}$ \\
\hline V. vallatus & $\mathrm{x}$ & $\mathrm{x}$ & $\mathrm{x}$ & & $\mathrm{x}$ & $\mathrm{x}$ & & & $\mathrm{x}$ & & & & & & $\mathrm{x}$ & & $\mathrm{x}$ & $\mathrm{x}$ & $\mathrm{x}$ & & $\mathrm{x}$ \\
\hline V. verrucosus & & $\mathrm{x}$ & & & & & & & & & $\mathrm{x}$ & & & & $\mathrm{x}$ & & & $\mathrm{x}$ & $\mathrm{x}$ & $\mathrm{x}$ & $\mathrm{x}$ \\
\hline V. ciliaris & & & & $\mathrm{x}$ & & & $\mathrm{x}$ & & & $\mathrm{x}$ & & $\mathrm{x}$ & & $\mathrm{x}$ & & & & $\mathrm{x}$ & & & \\
\hline V. communis & & & $\mathrm{x}$ & & & & & & & & & & & & & & & & & & \\
\hline V. galearis & & & & $\mathrm{x}$ & & & & & $\mathrm{x}$ & & & & & & & & & & & & \\
\hline V.pusillites & & & & & & & & $\mathrm{x}$ & & & & & $\mathrm{X}$ & & $\mathrm{x}$ & $\mathrm{x}$ & & $\mathrm{x}$ & $\mathrm{x}$ & & $\mathrm{x}$ \\
\hline \multicolumn{22}{|l|}{ V. agadesi } \\
\hline & $\begin{array}{l}r \\
r\end{array}$ & $\begin{array}{l}r \\
r\end{array}$ & $\begin{array}{l}r \\
\varepsilon\end{array}$ & $\begin{array}{l}r \\
0\end{array}$ & $\begin{array}{l}r \\
1\end{array}$ & $\begin{array}{l}r \\
v\end{array}$ & $\begin{array}{l}r \\
\mathbf{r}\end{array}$ & $\begin{array}{l}r \\
q\end{array}$ & r & $\begin{array}{l}r \\
1\end{array}$ & $\begin{array}{l}r \\
r\end{array}$ & $r$ & $\begin{array}{l}\boldsymbol{r} \\
\varepsilon\end{array}$ & $\begin{array}{l}r \\
0\end{array}$ & $\begin{array}{l}r \\
7\end{array}$ & $\mathbf{r}$ & $\begin{array}{l}\boldsymbol{r} \\
\boldsymbol{\Lambda}\end{array}$ & $\begin{array}{l}r \\
q\end{array}$ & $\varepsilon$ & $\varepsilon$ & $\begin{array}{l}\varepsilon \\
\boldsymbol{\varepsilon}\end{array}$ \\
\hline V. vallatus & $\mathrm{x}$ & $\mathrm{x}$ & & & & & $\mathrm{x}$ & $\mathrm{x}$ & $\mathrm{x}$ & $\mathrm{x}$ & $\mathrm{x}$ & $\mathrm{x}$ & $\mathrm{x}$ & & $\mathrm{x}$ & $\mathrm{x}$ & $\mathrm{x}$ & & $\mathrm{x}$ & & $\mathrm{x}$ \\
\hline V. verrucosus & & & & & & & & & & $\mathrm{x}$ & $\mathrm{x}$ & $\mathrm{x}$ & & $\mathrm{x}$ & $\mathrm{x}$ & $\mathrm{x}$ & $\mathrm{x}$ & & & & $\mathrm{x}$ \\
\hline V. ciliaris & & $\mathrm{x}$ & $\mathrm{x}$ & $\mathrm{x}$ & $\mathrm{x}$ & & & & & $\mathrm{x}$ & & & & & & $\mathrm{x}$ & $\mathrm{x}$ & $\mathrm{x}$ & & $\mathrm{x}$ & $\mathrm{x}$ \\
\hline \multicolumn{22}{|l|}{ V. communis } \\
\hline V. galearis & & & & & & & & $\mathrm{x}$ & & $\mathrm{x}$ & & & & & $\mathrm{x}$ & & & & & & \\
\hline V. pusillites & & & & & & $\mathrm{x}$ & & & $\mathrm{x}$ & & & & & & & $\mathrm{x}$ & & & & & \\
\hline $\begin{array}{l}\text { V. } \\
\text { microspinosis }\end{array}$ & & & & & & & & & & & & & & & & $x$ & & & & & \\
\hline \multicolumn{22}{|l|}{ V. agadesi } \\
\hline & $\varepsilon$ & $\varepsilon$ & $\varepsilon$ & $\varepsilon$ & $\varepsilon$ & $\varepsilon$ & $\varepsilon$ & 0 & 0 & $\begin{array}{l}0 \\
r\end{array}$ & 0 & 0 & 0 & 0 & $\begin{array}{l}0 \\
\mathbf{y}\end{array}$ & 0 & 0 & 7 & 7 & & \\
\hline V. vallatus & $\mathrm{x}$ & \begin{tabular}{|l|}
$\mathrm{x}$ \\
\end{tabular} & $\mathrm{x}$ & $\mathrm{x}$ & $\mathrm{x}$ & & $\mathrm{x}$ & & $\mathrm{x}$ & & $\mathrm{x}$ & & $\mathrm{x}$ & $\mathrm{x}$ & & \begin{tabular}{|l|}
$x$ \\
\end{tabular} & $\mathrm{x}$ & & $\mathrm{x}$ & & \\
\hline V. verrucosus & $\mathrm{x}$ & $\mathrm{x}$ & $\mathrm{x}$ & & $\mathrm{x}$ & $\mathrm{x}$ & $\mathrm{x}$ & $\mathrm{x}$ & $\mathrm{x}$ & & $\mathrm{x}$ & $\mathrm{x}$ & & & & & $\mathrm{x}$ & & & & \\
\hline V. ciliaris & $\mathrm{x}$ & & & & & $\mathrm{x}$ & & $\mathrm{x}$ & & & & $\mathrm{x}$ & $\mathrm{x}$ & $\mathrm{x}$ & & & & & $\mathrm{x}$ & & \\
\hline V. communis & & & & & & & & & & & & & & $\mathrm{x}$ & & & & & & & \\
\hline V. galearis & & & $\mathrm{x}$ & & & & & & & & & & & $\mathrm{x}$ & & & & & & & \\
\hline V. pusillites & & & & & & & & & & $\mathrm{x}$ & & & & $\mathrm{x}$ & & & $\mathrm{x}$ & & & & \\
\hline
\end{tabular}




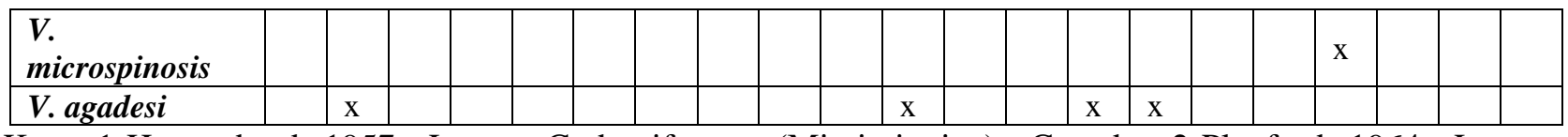

Key: 1-Hacquebard 1957, Lower Carboniferous (Mississippian), Canada; 2-Playford 1964, Lower Carboniferous (Mississippian), Canada; 3-Sullivan 1964a, Lower Carboniferous (Tournaisian), England; 4-Sullivan 1964b, Lower Carboniferous (Late Visean-Westphalian), England; 5-Neves and Owens 1966, Upper Carboniferous (Namurian), England; 6-Brass 1967, Lower Carboniferous (Tournaisian), Canada; 7Butterworth and Spiner 1967, Lower Carboniferous (Visean), England; 8-Neves and Dolby 1967, Upper Devonian-Lower Carboniferous, England; 9-Sullivan 1968, Lower Carboniferous (Tournaisian), Canada; 10-Hibbert and Lacey, 1969, Lower Carboniferous, Wales; 11-Varma 1969, Lower Carboniferous, Canada; 12-Neves et al., 1973, Lower Carboniferous, England; 13-Clayton et al., 1974, Upper Carboniferous,Ireland; 14-Neves ans Ioannides 1974, Lower Carboniferous (Dinantian), Scotland; 15Higgs 1975, Lower Carboniferous (Tournaisian (late Tn2-early Tn3 Pc zone)), Ireland; 16-Playford 1976, Upper Devonian-Lower. Carboniferous, Australia; 17-Clayton et al., 1977a, Lower Carboniferous (Tournaisian), Ireland; 18-Clayton et al., 1977b, Carboniferous, Western Europe; 19-Keegan 1977; Late. Devonian-Early. Carboniferous, Ireland; 20-Owens et al., 1977, Tournaisian, Ireland; ; 21-Clayton et al. 1978, Lower Carboniferous (Tournaisian late Tn2-early Tn3), British Isles; 22-Keegan and penney 1978, Lower Carboniferous, Ireland; 23-Loboziak and Alpern, 1978, Visean, Niger; 24-Attar et al., 1980, Lower Carboniferous (Visean), Algeria; 25-Massa et al., 1980, Lower Carboniferous (Visean), Libya; 26-Utting 1980; 27-Higgs and Russel 1981, Devonian (Strunian), Ireland; 28-Van Der Zwan, 1981, Carboniferous, Ireland; 29-Welsh and Owens 1983, Carboniferous (Dinantian), England; 30-Byvscheva et al., 1984, Upper Devonian/Lower Carboniferous, Russia; 31-Higgs 1984, Lower Carboniferous (Visean), Ireland; 32-Higgs and Clayton, 1984, Lower Carboniferous (Tournaisian late Tn2-early Tn3), England; 33-Clayton and Loboziak, 1985, Lower Carboniferous Visean - Namurian, Libya; 34-Sultan 1985, Lower Carboniferous (Tournaisian), Egypt; 35-Loboziak et al. 1986, Lower Carboniferous, North Africa; 36-Utting 1987, Lower Carboniferous (Tournaisian late Tn2 Pc zone), Canada; 37-Higgs et al. 1988, Lower Carboniferous (Tournaisian late Tn2-Tn3 Pc-Cm Biozone), Ireland; 38-Loboziak and Clayton 1988 Lower Carboniferous, Libya; 39-McPhilemy 1988, Lower Carboniferous, Ireland; 40-Turner and Spinner 1988, Lower Carboniferous (Tournaisian Tn2, Pc Biozone), England; 41-Coquel and Latreche 1989, DevonianCarboniferous, Algeria; 42-Utting et al. 1989, Lower Carboniferous (Tournaisian Tn2-Tn3, Pc-Cm zone), Canada; 43-Loboziak et al., 1990, Lower Carboniferous (Dinantian), Morocco; 44-Loboziak et al. 1991, Lower Carboniferous (Tournaisian late Tn2-Tn3, Pc-Cm zone), Brazil; 45-Higgs et al., 1992, Lower Carboniferous (Tournaisian late Tn2, Pc zone) Belgium; 46-Loboziak et al., 1992, Upper Devonian Strunian- Lower Carboniferous, Tournaisian-Visean), Brazil; 47-Avchimovitch et al., 1993, Upper Devonian-Lower Carboniferous, Bylorussia; 48-Kora 1993, Lower Carboniferous (Visean), Egypt; 49Loboziak et al., 1993 Middle/Upper Carboniferous (BP Biozone), Brazil; 50-Martel et al. 1993, Upper Devonian-Lower Carboniferous, Canada; 51-Playford 1993, Devonian/ Carboniferous, Australia; 52Ghavidel-Syooki 1994, Upper Devonian, Iran; 53-Ravn et al., 1994, Lower Carboniferous, Syria; 54Clayton 1995, Lower Carboniferous, Saudi Arabia; 55-Turner et al., 1995, Lower Carboniferous (late Visean), Britain; 56-Abelsselam-Rouighi and Coquel 1997, Carboniferous (Tournaisian-Visean and Namurian), Algeria; 57-Loboziak et al., 1997; 58-Owens et al., 1998, Middle Carboniferous, Saudi Arabia; 59-Clayton et al. 2000, Upper Devonian-Lower Carboniferous (Tn-Visean), Saudi Arabia; 60-Melo and Loboziak 2000; 61-Amaral et al., 2001, Carboniferous, Brazil.

\section{CONCLUSIONS}

The detailed study and the correlation between Iraq, adjacent regions and the world based on the zonal species of the genus Vallatisporites revealed that:

1- The presence of $V$. pusillites (which is confined to the Devonian strata in the world) in the Carboniferous strata of Akkas- 1 and $\mathrm{Kh} 5 / 1$ boreholes in Iraq need an explanation. The recent meeting of Vallatisporites Group assigned all Vallatisporites with coarse ornaments to the species $V$. hystricosus, so that the $V$. pusillites of Iraq must be recorrected. 
Amer D. Nader et al. 
A Detail Study of the Genus Vallatisporites as a Lower ...... 
Amer D. Nader et al. 
2-Iraq, Syria, Saudi Arabia, Iran and North Africa belongs to Aratrisporites saharaensis province in the Carboniferous period which is different from the Vallatisporites province of Turkey, North America and Europe. This difference in the provinces was reflected by the longer ranges of some Vallatisporites species as follow:

a- $V$. vallatus and $V$. verrucosus were previously recorded from late Tournaisian age in both North America and Europe and the range was extended to the late Visean-early Namurian age in Iraq, Syria, Saudi Arabia and North Africa.

b- $V$. ciliaris extend its range from Visean-early Namurian age in Europe and North America to late Tournaisian age in Iraq and Algeria.

c- $V$. banffensis extend its range from early Tournaisian age according to previous studies in the world to late Tournaisian-early Visean age from Syria and Iraq (this study).

d-The occurrences of the species $V$. microspinosis from lower Carboniferous (Tournaisian to late Visean) and early Namurian strata from Iraq only, was disparity with Higgs et al. (1988) who limited its lower and upper range to be restricted to the Tournaisian age, so that this species should need further studies in the Middle East and North Africa to document its correct ranges and confirms its occurrences from Iraq (this study).

e-The confined occurrences of endemic species $V$. agadesi in Iraq(this study), Syria, Saudi Arabia and North Africa confirm that these regions belong to one paleoprovince (Aratrisporites saharaensis) during the Carboniferous period.

\section{REFERENCES}

Abdesselam- Rouighi, F.-F., and Coquel, R., 1997: Palynology of the uppermost Devonian-Lower Carboniferous in the South-East of the Jllizi Basin (Algerian Sahara). The first appearance of lycospores in the stratigraphical series, Ann. Soc. Geol. Du Nord. T.S. ( $\left.2^{\text {nd }}\right)$, pp.47-57.

Al-Mola, N. A. 2002: Palynology of part of the stratigraphic section in borehole KH5/1 in Western Iraqi Desert .Unpub. M. Sc. Thesis, Univ. Mosul ،V0- I: in Arabic.

Amaral, P. G. C., Branco, F. R., De Souza, P. A. \& De Oliveira, M. E. C., 2001: Macro and Microphytofossils study of the itarare Subgroup at KM 96 of the Bandeirantes Highway, Campinas Municipality, Brazil .An. Acad. Bras. Ciene. 73(3): Rio Janeiro.

Attar, A., Fournier, J., Candilier, A. M. and Coquel, R., 1980: Etude palynologique de Devonien terminal et du Carbonifere inferieur du bassin d Illizi (Fort Polignac) Algerie. Revue de I Institut Francais du Petrole, 35: pp.585-619.

Avchimovitch,v., Byvsheva, T. V. ,H, K., Streel, M., and Vmnova, T. V. 1988: Miospore systematics and stratigraphic correlation of Devoniann-Carboniferous boundary deposits in the European part of the USSR and Westren Europe. Courier forschungs-institut Senckenberg, 100: pp.169-191.

Avchimovitch, V. I., Tchibrikova, E. V., Obukhovskaya, T. G., Nazarenko, A. M., Umnova, V. T., Raskatova, L. G., Mantsurova, V. N., Loboziak, S. and Streel, 
M., 1993: Middle and Upper Devonian miospore zonation of Eastern Europe. Bull. Centres Rech. Explor.-Prod. Elf Aquitaine, 17: pp.79-147.

Becker, G. Bless, M. J. M., Streel, M. \& Thorez, J., 1974: Palynology and Ostracod distribution in the Upper Devonian and basal Dinantian of Belgium and their dependence of sedimentary facies .Mede. Rijks. Geol. Dienst., n. s., 25: pp.9-99, 30 pls.

Brass, M. S., 1967: Carboniferous and Permian spores of Canada. Geo. Surv. Can., Paper 67-11, : pp.1-94.

Butterworth, M. A. and Spinner, E. G., 1967: Lower Carboniferous spores from NorthWest England .Palaeont., 10: pp.1-24.

Byvscheva, T. V., Higgs, K. and Streel, M., 1984: Spore correlations between the Rhenish Slate mountains and the Russian Platform near The DevonianCarboniferous boundary. Courier Forsch. -Inst. Senckenberg., 67: pp.37-45.

Byvsheva, T. V. 1985: Spores from Tournaisian and Visean stages of the Russian Plate-In: Menner, V. V. \& Byvsheva, T. V (eds): Atlas of spores and pollen of phanerozoic oil gas bearing strata of the Russian and Turanian plates.Vsesoyuzny Nauchnoc- Issiedovatel skuy Geologicheskiy Institut (VN/GNI), Trudy, 2533, 80-158 (in Russian).

Clayton,G.1985: Dinantian miospores and inter-continental correlation.c.r.10eme Cong.int Strat.Geol.Carb., Madrid,1983,4, pp.9-23.

Clayton, G., 1995: Carboniferous miospore and pollen assemblages from the Kingdom of Saudi Arabia. Review of Palaeobotany and Palynology, 89: pp.115-123.

Clayton, G., and Loboziak, S., 1985: Early Carboniferous (Early ViseanSerpukhovian). In: B. Thusu and B. Owens (Edts.), The Palynostratigraphy of Northeast Lybia .Jour .Micropalaeont., 4(1): pp.83-92.

Clayton, G., Colthurst, J. R. J., Higgs, K., Jones, G. L. L. \& Keegan, J. B., 1977a: Tournaisian miospores and conodonts from County Kilkenny. Geol. Surv. Ireland. Bull., 2: pp.99-106.

Clayton, G., Coquel, R., Doubinger, J. Gueinn, K. J., Loboziak, S., Owens, B. and Streel, M., 1977b: Carboniferous miospores of western Europe: Report of the Commission internationale de microflore du Paleozoique working group on Carboniferous stratigraphical palynology., Meded. Rijks. Geol. Dienst, 29: pp.171.

Clayton, G., Higgs, K., Gueinn, K. J. \& Van Gelder, A., 1974: Palynological correlation's in the Cork Beds (Upper Devonian- ?Upper Carboniferous) of southern, Ireland .Proc. R. Ir. Acad., 746: pp.145-156.

Clayton, G., Higgs, K., Keegan, J. B. and Sevastopulo, G. D., 1978: Correlation of the palynological zonation of the Dinantian of the British Isles .Palinologia 1: pp.137-147.

Clayton, G., Owens, B., Al-Hajri, S. and Filatoff, J., 2000: Latest Devonian and Early Carboniferous Miospore assemblages from Arabia. In: Al-Hajri, S. and Owens, B. (Eds.), PetroLink, Bahrain, pp.146-153.

Coquel, R., Loboziak, S., Stampli, G. and Stampfli-Voille,B 1977: Palynologie du Devonian superieur et du Carbonifere inferior dans 1 Elburz Oriental(Iran Nordest). Rev. Micropaleont.,20. pp.59-71. 
Coquel, R. and Latreche, S., 1989: Palynological study of the Illerene Formation (Devonian-Carboniferous) in the Illizi Basin (Eastern Algerian Sahara). Palaeontographica Abt. B, 212(1-3): pp.47-70.

Coquel, R., Doudinger, J. and Massa, D., 1988: Nouvelles donnees palynologiques sur 1 intervalle Carbonifere Viseen / Namurien Bassin de Rhadames (Libye). Revue de 1 Instutut Francais du Petrole, 43(1): pp.3-16.

Dolby, G. and Neves, R., 1970: Palynological evidence concerning the DevonianCarboniferous boundary in the Mendips, England. C, r. $6^{\text {th }}$ Cong. Avanc. Etud. Stratigr. Geol. Carb., Sheffield (1967), 2: pp.631-646, 2pls.

Ghavidel-Syooki, M. 1994: Upper Devonian acritarchs and miospores from the Geirud Formation in Central Alborz Raug, Northern Iran .J. Sci. I. R. Iran, 5(3): pp.103122.

Hacquebard, P. A., 1957: Plant spores in coal from the Horton group (Mississippian) of Nova Scotia .Micropaleont., 3(4): pp.301-324.

Hebbert, F. A. and Lacey, W. S., 1969: Miospores from the Lower Carboniferous Basement Beds in the Menai Straits Region of Caernarvonshire, North Wales. Palaeont., 12(3): pp.420-440.

Higgs, K. and Clayton, G., 1984: Tournaisian miospore assemblages from Maesbury in the Eastern Mendips, England . J. Micropalaeont., 3(1): pp.17-28.

Higgs, K. T., 1975: Upper Devonian and Lower Carboniferous miospore assemblages from Hook Head, County Wexford, Ireland .Micropaleontology:(દ)r। , pp. 393419.

Higgs, K. T., 1984: Stratigraphic palynology of the Carboniferous rocks in northwest Ireland .Geol. Survey Ireland, Bull., 3: pp.171-201.

Higgs, K. T., and Russell, K. J., 1981: Upper Devonian microfloras from southeast Iveragh, County Kerry, Ireland .Geol. Surv. Irl. Bull: 17, pp.3-50

Higgs, K. T., Clayton, G. and Keegan, J. B., 1988: Stratigraphic and systematic palynology of the Tournaisian rocks of Ireland ،.Geol. Surv. Irel. Spec. Pap ،. ।: pp.7-9щ

Higgs, K. T., Dreesen, R., Dusar, M. and Streel, M., 1992: Palynostratigraphy of the Tournaisian (Hastarian) rocks in the Namur Synclinorium, West Flanders, Belgium ،Rev. Palaeobot. Palynol:149, pp.72-158

Hughes, N. F. and Playford, G., 1961: Palynological Retonnaissan of the Lower Carboniferous of Spitsbergne .Micropalaeontology, 7: pp.27-44.

Hughes, N. F., Dettmann, M. E. and Playford, G., 1962: Sections of some Carboniferous dispersed spores .Palaeontol., 5: pp.247-252.

Jansonius, J. 1962: Palynology of Permian and Triassic sediments, Peace River Area, Western Canada .Palaeontographica B, 110 : pp35-98.

Kedo, G. I., 1957: Stratigraphic significance of Hymenozonotriletes pusillites sp. n., Dokl. Akad. Nauk. BSSR, 1: pp.21-23.

Keegan, J. B. and Penny, S. R., 1978: Lower Carboniferous miospore assemblages from the Portlaw Area, County Waterford, Ireland. Pollen et Spores, 20: pp.569581 . 
Keegan, J. B., 1977: Late Devonian and Early Carboniferous miospores from the Galley Head-Leap Harbour region of Southwest Ireland .Pollen et Spores, 19(4): pp.545-573.

Kora, M., 1993: Carboniferous miospores assemblages from the Abu Rodeiyim Boreholes, west-central Sinai, Egypt .Rev. Micropaleontol 36(3): pp.235-255.

Loboziak, S. and Clayton, G., 1988: The Carboniferous palynostratigraphy of northeast Libya. In: El-Arnauti, A .et al., (eds.), Subsurface Palynostratigraphy of Northeast Libya, Garyounis Univ. Publ., : pp.129-149.

Loboziak, S. and Alpern, B., 1978: Le Bassin Houiller Visean d Agades (Niger). III:

Les microspores .Palinologia, num. Extraord., 1: pp.55-67.

Loboziak, S., Streel, M., Caputo, M. V. and de Melo, J. H. G., 1991:Evidence of West European defined miospore zones in the uppermost Devonian and Lower Carboniferous of the Amazonas Basin Brazil .Geobios, 1(21): pp.5-11.

Loboziak, S., Streel, M., Caputo, M. V. and de Melo, J. H. G., 1992: Middle Devonian to Lower Carboniferous miospore stratigraphy in the Central Parnaiba

Basin Brazil .Ann. Soc. Geol. Belg., 115(1): pp.215-226.

Loboziak, S., Vachard, D., Fadli, D. and Streel, M., 1990: Datation par miospores et Foraminiferes du Tournaisien et du Visean de I’Oued Zemrine (Massif des Madakra, Maroc .Jour. Afrc. Ear. Sci., 11(1/2): pp.113-118. [in: French].

Loboziak, S., Clayton, G. and Owens, B. 1986 :Aratrisporites saharensis sp. Nov.: A characteristic Lower Carboniferous miospore species of North Africa. Geobios, 19(4): pp.497-503.

Loboziak, S., Melo, J. H. G., Matsuda, N. S. and Quadros, L. P., 1997: Miospore biostratigraphy of the type Barreirinha Formation (Curua Group, Upper Devonian) in the Tapajos River Area, Amazon Basin, North Brazil, BCREDP, 21(1): pp.187-205.

Loboziak, S., Streel, M., Caputo, M. V. and Melo, J. H. G., 1993: Middle Devonian to Lower Carboniferous miospores from selected boreholes in Amazonas and Parnaiba Basins (Brazil): additional data, synthesis, and correlation. Doc. Lab. Geol. Lyon, 125: pp.277-289.

Martel, A. T., McGregor, D. C. and Utting, J., 1993: Stratigraphic significance of Upper Devonian and Lower Carboniferous miospores from the type area of the Horton Group, Nova Scotia .Can. J. Earth Sci., 30: pp.1091-1098.

Massa, D., and Moreau-Benoit, A., 1976: Essai de synthese stratigraphique et palynologique du Systeme Devonien en Libye occidentale. Revue de 1 Institut Francais de Petrole, v.31, pp.287-333.

Massa, D., Coquel, R., Loboziak, S. and Taugourdeau-Lantz, J., 1980: Essai de synthese stratigraphique et palynologique du Carbonifere en Libye occidentale. Ann. Soc. Geol. Nord, 99: pp. 429-442 .

McGregor, D. C., 1970: Hymenozonotriletes lepidophytus Kedo and associated spores from the Devonian of Canada. Congres et Colloques Univ. Liege, 55:315-326. pls. pp.21-23. 
McPhilemy, B., 1988: The values of Fluorescence microscopy in Routine palynofacies analysis: Lower Carboniferous successions from Counties Armagh and Roscommon, Ireland .Rev. Palaeobot. Palynol., 56: pp.45-359.

Melo, J.H.G. Loboziak, S., 2000: Visean miospore biostratigraphy and correlation of the Poto Formation (Parnaba Basins, Northern Brazil), Rev. Palaeobot. Palynol., 112: pp.147-165.

Nader, A., Khalaf, F. and Al-Lamy, F. 2002: Palynostratigraphy of part of Carboniferous strata in borehole Akass-1 Western Iraq .Unpub. M. Sc. Thesis, Univ. Mosul ، 9V- 1: , [in Arabic].

Nader, A. D., Mekha, N. H. and Khalaf, F. H., 1997: Palynostratigraphy of the subsurface Suffi Formation from borehole KH5/1, Western Iraqi desert .Abhath Al-Yarmook Sci. Engen. Ser., 6: pp.25-67. [in: Arabic].

Neves, R., 1972: Recent developments in Carboniferous palynology. C. r. 7th Cong. Avanc. Etud. Stratigr. Geol. Carb., Krefeld, 1: pp.127-137.

Neves, R. and Dolby, G., 1967: An assemblage of miospore from the Portishead Beds (Upper Old Red Sandstone) of the Mendip Hills, England. Pollen et Spores, 9(3): pp.607-614.

Neves, R. and Owens, B., 1966: Some Namurian camerate miospores from the English Pennines .Pollen et Spores, 8(2): pp.222-359.

Neves, R., and Ioannides, N. S., 1974: Palynology of the Lower Carboniferous (Dinantian) of the Spilmersford borehole, East Lothian, Scotland .Geol. Surv. Gr. Br., 45: pp.73-97.

Neves, R., Gueinn, K. J., Clayton, G., Ioannides, N. S. and Neville, R. S. W., 1972: A scheme of miospore zones for the British Dinantian. Compte Rendu, Septieme congres international de stratigraphic et de geologie du carbonifere, Krefeld 1971, 1: pp.347-353.

Neves, R., Gueinn, K. J., Clayton, G., Ioannides, N. S., Neville, R. S. W. and Kruszewska, K., 1973: Palynological correlations within the Lower Carboniferous of Scotland and northern England .Trans. Roy. Soc. Edinb., 69: pp.23-70.

Owens, B., 1970: A review of the palynological methods employed in the correlation of Paleozoic sediments .Congres et Colloques Univ. Liege, 55: pp.99-112.

Owens, B., Filatoff, J., Clayton, G. and Al-Hajri, S., 2000: Evidence of Mid Carboniferous Miospores Assemblage from Central Saudi Arabia. (Eds.), PetroLink, Bahrin, pp.154-167.

Owens, B., Gueinn, K. J. and Cameron, I. B., 1977: A Tournaisian miospore assemblage from the Altagoan Formation (Upper Calciferous Sandstone), Draperstown, Northern Ireland .Pollen et Spores, 19: pp.313-324.

Paproth, E. and Streel, M., 1970: Correlations biostratigraphiques pres de la limite Devonian Carbonifere entre les facies littoraux ardennais et les facies bathyaux rhenans. Congres et Colloques Univ. Liege, 55: pp.365-398.

Playford, G., 1964: Miospores from the Mississippian Horton Group, eastern Canada . Geol. Surv. Canada Bull., 107: pp.1-47. 
Playford, G., 1976: Plant microfossils from the Upper Devonian and Lower Carboniferous of the Canning Basin, Western Australia .Palaeontographica B, 158: pp.1-71.

Playford, G., 1993: Miospores and Organic-walled Microphytoplankton characteristic of strata Contiguous with the Devonian-Carboniferous boundary .Comptes Rendus, 22(1): pp.127-160.

Ravn, R. L., McPhilemy, B., Rutherford, M., Talli, S. and Bahra, G., 1994: Late Devonian and Early Carboniferous palynostratigraphy and its application in northeastern Syria. In: M. D. Simmons (Edt.), Micropalaeontology and Hydrocarbon Exploration in the Middle East, Chapman and Hall, London, :5-21.

Schrank, K. 1984: Paleozoic and Mesozoic palynology from the foram -1 well (Western Desert, Egypt).- N. Jahrb.Geol. Palaont. 2: pp. 95-112.

Segroves, K. L., 1970: Permian spores and pollen grains from the Perth Basin, Western Australia .Grana 10: pp.47-73, 11pls.

Smith, A. V. H. and Butterworth, M. A., 1967: Miospores in the coal seams of the Carboniferous of Great Britain. Spec. Pap. Palaeont., I, Palaeont. Assoc., London, 1: pp.1-324.

Staplin, F. L. and Jansonius, J., 1964: Elucidation of some Palaeozoic Densospores. Palaeontographica, 114, pp.95-117.

Streel, M. 1970: Distribution stratigraphique et geographique d 'Hymenozonotriletes lepidophytus Kedo, d' Hymenozonotriletes pusillites Kedo et des assemblages Tournaisiens. Congres et Colloques Univ. Liege, 55: pp.121-147.

Sullivan, H. J., 1964a: Miospores from the Lower Limestone Shales (Tournaisian) of the Forest of Dean Basin, Gloucestershire. C. r. 5th Cong. Avanc. Etud. Stratigr. Geol. Carb., Paris (1963), 3: pp.1249-1259.

Sullivan, H. J., 1964b: Miospores from the Drybrook Sandstone and associated measures in the Forest of Dean Basin, Gloucestershire .Palaeontology, 7(3): pp.351-392.

Sullivan, H. J., 1965: Palynological evidence concerning the regional differentiation of upper Mississippian flora. Pollen et Spores,7, pp.539-63.

Sullivan, H. J., 1968: A Tournaisian spore flora from the Cementstone Group of Ayrshire, Scotland .Palaeont: 11, pp.116-131

Sultan, I. Z., 1985: Tournaisian plant microfossils from the northern part of the Western Desert of Egypt. Bull. Fac., Alex. Univ., Alexandria, 25(3): pp.1-25.

Turnau,E. 1978: Spore zonation of upper most Devonian and lower Carboniferous deposits of western Pomerania. Med. Rijks geol. Dienst., 30-1, pp.1-35.

Turnner, N. \& Spinner, E., 1988: A palynological study of the Lower Carboniferous strata (Dinantian) from Titterstone Clee, Shropshire, England .Pollen et Spoires, 30(3-4): pp.429-359.

Turnner, N., Spinner, E., \& Dorning, K. J., 1995: A palynological study of the Lower Carboniferous Lydebrook Sandstone and adjacent Late Wenlock and Langsettain strata, Shropshire, England .Review of Palaeobotany \& Palynology, 84: pp.305329.

Utting, J., 1980: Palynology of the Windsor Group (Mississippian) in a borehole at Stewiacke, Shubenacadie Basin, Nova Scotia. Canadian Journal of Earth Sciences, 17(8): pp.1031-1045. 
Utting, J., 1987: Palynostratigraphic investigation of the Albert Formation (Lower Carboniferous) of New Brunswick, Canada .Palynol: 11, pp. 73-96

Utting, J., Keppei, J. D. and Giles, P. S., 1989: Palynology and Stratigraphy of the Lower carboniferous Horton Group, Nova Scotia .Cont. Can. Paleont., Geol. Surv. Can., Bull., 396: pp.117-143.

Van der Zwan, C. J., 1981: Palynology, phytogeography and climate of the Lower Carboniferous .Palaeogeog. Palaeoclimat. Palaeoecol., 33: p.279-310.

Varma, C. P., 1969: Lower Carboniferous miospores from the Albert Oil Shales (Horton Group), New Brunswick, Canada. Micropaleontol., 15(3): pp.301-324.

Vavrdova, M., Bek, J., Dufka, P., and Isaacson, P., 1996: Palynology of the Devonian (Lochkovian to Tournaisian) sequence, Madre de Dios Basin, northern Bolivia. Bulletin of the Czech Geological Survey., 71(4): pp.333-350

Welsh, A. and Owens, B., 1983: Early Dinantian miospore assemblages from the Caldon Low borehole, Staffordshire, England. Pollen et Spores, 25: pp.253-264.

Winslow, M. R., 1962: Plant spores and other microfossils from Upper Devonian and Lower Mississippian rocks of Ohio. Prof. Pap. U. S. Geol. Surv., 364:93pp., 22pls.

\section{Explanation of plate 1}

1-Vallatisporites agadesi Loboziak \& Alpern 1978, 11382, R 2.6/131.5, 72.5 $\mu \mathrm{m}$.

2-Vallatisporites agadesi Loboziak \& Alpern 1978, 11381, R 0.2/130.9, 60 $\mu \mathrm{m}$.

3-Vallatisporites ciliaris (Luber) Sullivan1964b, 11381, R0.1/131.1, 65 $\mu \mathrm{m}$

4-Vallatisporites ciliaris (Luber) Sullivan1964b, 11381, R $0 / 129,72 \mu \mathrm{m}$.

5-Vallatisporites ciliaris (Luber) Sullivan1964b 11381, R 0.4 /128.9, 67 $\mu \mathrm{m}$.

6-Vallatisporites ciliaris (Luber) Sullivan1964b, 11382, L 4.1/123.0, 60 $\mu \mathrm{m}$.

7-Vallatisporites microspionosus Higgs et al. 1988, 11382, L 6.8/132, 46 $\mu \mathrm{m}$.

8-Vallatisporites microspionosus Higgs et al. 1988, 11381, L 0/129, 72 $\mu \mathrm{m}$.

9-Vallatisporites microspionosus Higgs et al. 1988, 11381, R 0.7/119, 50 $\mu \mathrm{m}$.

10-Vallatisporites vallatus Hacquebard 1957, 11382, R 0.9/119, 50 $\mathrm{m}$.

11-Vallatisporites vallatus Hacquebard 1957, 11382, R 5.1/129, 48 $\mu \mathrm{m}$.

12-Vallatisporites vallatus Hacquebard 1957, 11382, L 8.6/132, 46 $\mu \mathrm{m}$.

13-Vallatisporites verrucosus Hacquebard 1957, 11971, R 0.6/113, 52 $\mu \mathrm{m}$.

14-Vallatisporites verrucosus Hacquebard 1957, 11971, R 11/122.3, 62 $\mu \mathrm{m}$.

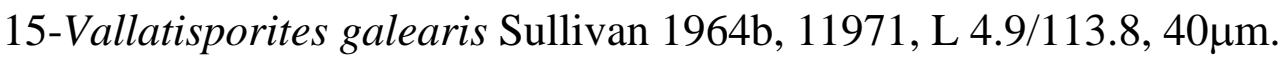

16-Vallatisporites vallatus Hacquebard 1957, 11382, R 6.8/132, 45 $\mathrm{m}$. 


\section{PLATE-1}

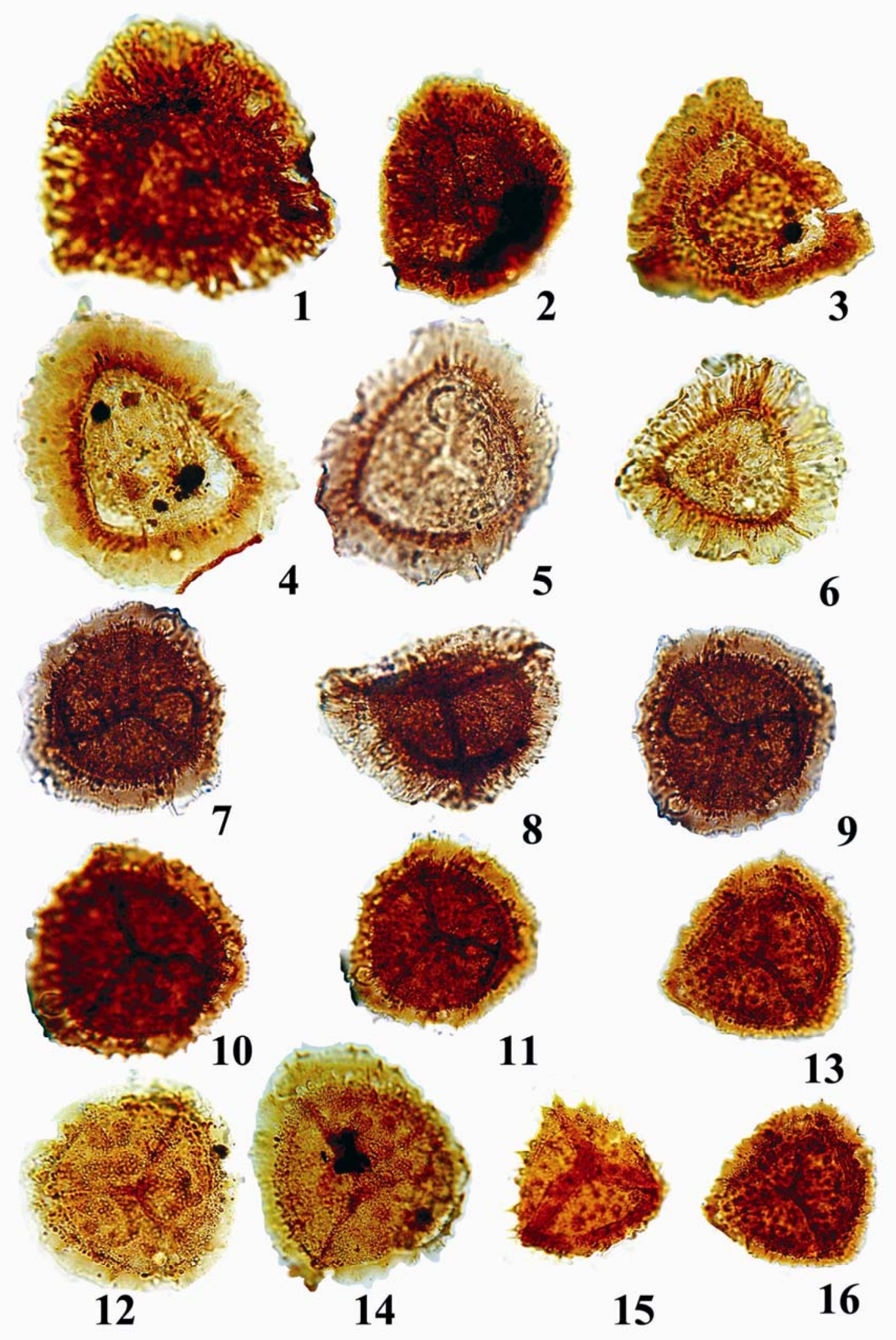

